Anna Pająk

Uniwersytet Jagielloński

\title{
Polityka (nie)pamięci o sowieckiej przeszłości Gruzji w czasie prezydentury Micheila Saakaszwilego
}

\begin{abstract}
After the October Revolution and the collapse of the Russian Empire, Georgia was formed in the Democratic Republic of Georgia, which was occupied by the Bolsheviks in 1921, thus launched a seventy-year period of Soviet history in Georgia. Micheil Saakashvili was the third president of an independent Georgia after the collapse of the Soviet Union. When he came to power in 2003 he undertook activities in almost all spheres of social and political life, that are characterized primarily by the anti-Russian and anti-Soviet dimension. Article "The policy of (non) remembrance of Georgia's Soviet past during Micheal Saakashvili's presidency" is an analysis of the actions taken in the politics of memory by the Georgian president, which fundamentally devastated the Russian and Soviet past of Georgia, and thus shape a new type of society, uncritically appealing to the bringing the memory of the Soviet legacy from "70 years of sojuza" to "70 years of occupation". The text was mainly based on the internet articles and publications of Georgian scientists and the author's own research.

Keywords: politics of memory, Georgia, Micheil Saakashvili
\end{abstract}

\section{Резюме}

В результате Октябрьской революции и распада Российской империи была провозглашённа в Грузинская Демократиическая Респуублика. В 1921 году, только после трех лет существования, была она занята большевиками, что привело к семидесятилетнему периоду советской истории Грузии. Пришедший к власти в 2003 году Михаил Саакашвили стал третьим после распада Советского Союза президентом независимого грузинского государства. Проводившаяся ним деятельность характеризовалась прежде всего антироссийским и антисоветским измерением практически во всех сферах общественной и политической жизни. Статья «Политика (не) памяти о советском прошлом Грузии в период президентства Михаила Саакашвили»- это анализ действий политической политики, предпринятых бывшим 
президентом Грузии, которые в корне опустошили российское и советское прошлое Грузии и, таким образом, сформировали новый тип общества, воспрминающий совецкое прошлое не как «70 лет союза» а «70 лет оккупации». Текст был подготовлен главным образом на основе статей и интернет-изданиях грузинских ученых и авторов собственных исследований.

Ключивие слова: политика памяти, Грузия, Михаил Саакашвили

Po rewolucji październikowej w 1917 roku Gruzini, podobnie jak inne narody byłego Imperium Rosyjskiego, ogłosili niepodległość i utworzyli 26 maja 1918 roku Demokratyczną Republikę Gruzji. W ciągu trzech lat swego istnienia rządzona była ona przez lokalną socjaldemokrację - mienszewików, z Noem Żordanią i Noem Ramiszwilim na czele, aż w 1921 roku została podbita przez bolszewików. Po tej klęsce rząd gruziński ewakuował się do Stambułu. Bolszewicy utworzyli Gruzińską Socjalistyczną Republikę Radziecką, która 12 marca 1922 r. weszła w skład Zakaukaskiej Republiki Radzieckiej i pozostała w niej do 5 grudnia 1936 r. W tymże roku rozwiązano Zakaukaską Federacyjną SRR, skutkiem czego Gruzińska SRR (podobnie jak Armeńska SRR i Azerbejdżańska SRR) stała się bezpośrednim członkiem ZSRR. Związek Socjalistycznych Republik Radzieckich rozpadł się 26 grudnia 1991 roku, po niemal siedemdziesięciu latach istnienia, w wyniku czego niepodległość odzyskało czternaście byłych republik radzieckich Europy Wschodniej, Zakaukazia i Azji Centralnej.

Siedemdziesiąt lat istnienia ZSRR oznaczało dla owych państw czas całkowitej wręcz degradacji ich wcześniejszych systemów państwowych, historii, świadomości społecznej, które przez niemal cały XX wiek sprowadzone były jedynie do struktur politycznospołecznych systemu radzieckiego. Rozpad ZSRR oznaczał zatem dla niepodległych państw konieczność stworzenia na nowo podstaw swego istnienia oraz - o czym traktuje artykuł narracji historycznych narodu. W dyskursie społecznym zaczęto mówić o potrzebie nowego systemu wartości i problemie pamięci historycznej. Jednym z fundamentów tych państw 
okazała się właśnie odpowiednia polityka historyczna, która miała pomóc w stworzeniu od początku świadomości narodowej społeczeństwa. Zadanie to dla wielu państw okazało się niezwykle trudne. Historiografia i polityka historyczna ZSRR silnie wpłynęły na mieszkańców byłych republik. Sowietyzacja owych obszarów, wykształcenie homo sovieticusa, kreowanie przez władze wspólnych więzi historycznych i wspólnej pamięci historycznej, podkreślanie znaczenia wielkiej wojny ojczyźnianej i rewolucji proletariatu wszystko to odcisnęło piętno na narodach byłego ZSRR. W krajach tych polityka historyczna stała się polem bitwy dla konkurencyjnych narracji, a historia zaczęła służyć osiąganiu celów politycznych. W związku z powyższym zainteresowanie fenomenem pamięci historycznej na obszarze postradzieckim było ogromne. W procesie państwowotwórczym historia okazała się wyjątkowo ważnym czynnikiem politycznym, zaś rozbieżność politycznych nastrojów ekwiwalentem różnej interpretacji historycznej przeszłości. Do uprawiania polityki pamięci służą między innymi badania naukowe, edukacja i wychowanie, muzea, izby pamięci, media masowe, a także kalendarz świąt państwowych i kult narodowych bohaterów (Wawrzyński, 2013). Władze korzystają $\mathrm{z}$ tych możliwości, by kształtować rzeczywistość w oparciu o przeszłość lub też nawet za jej pomocą.

Gruzja jako jedna z byłych republik radzieckich po odzyskaniu niepodległości w 1991 roku również stanęła przed wyzwaniem wykreowania odpowiedniej, własnej narracji historycznej. Przez siedemdziesiąt lat ludność gruzińska była sowietyzowana, a pamięć o niepodległej przeszłości - wymazywana z przestrzeni publicznej i świadomości ludzkiej. Rzetelna analiza polityki historycznej prowadzonej w Gruzji po roku 1991 jest niełatwym zadaniem. Zaczynając od szowinistycznej polityki Zwiada Gamsachurdii, przez ambiwalentne działania Eduarda Szewardnadzego, a na antyrosyjskiej i antyradzieckiej polityce Micheila Saakaszwilego kończąc, stanowi ona wyjątkowo interesujący obszar badań. Niniejszy artykuł podejmuje próbę analizy działań podjętych w obszarze polityki historycznej przez Micheila Saakaszwilego, które miały wyprzeć rosyjską i radziecką przeszłość Gruzji, a przez to ukształtować nowy typ społeczeństwa, bezkrytycznie niemal odwołujący się do europejskości narodu gruzińskiego. Znamienne wydają się słowa Saakaszwilego, który jako prezydent nieustannie podkreślał przynależność swojej ojczyzny do świata europejskiego, odżegnując się jednocześnie od jej wspólnej z Rosją i Związkiem Radzieckim karty historycznej: „Właśnie u nas, tutaj w Gruzji, określane są losy nowego, europejskiego i światowego porządku. Gruzja pełni znaczącą misję w regionie, jest pionierem i przywódcą" (Саакашвили: В Грузии..., 2008). 
Antyrosyjska i antyradziecka narracja wzmogła się po wojnie rosyjsko-gruzińskiej w sierpniu 2008 r. Gruzińscy historycy i politycy podkreślali paralelizm między radziecką okupacją z 1921 r. i wojną z 2008 r. Aby wspierać tę analogię, gruziński rząd zaczął na nowo oceniać przeszłość, burzyć stare i tworzyć nowe miejsca pamięci oraz uruchamiać specjalne programy w szkołach i na uniwersytetach (Toria, 2016, s. 317). Radykalne działania Saakaszwilego należy traktować kompleksowo, gdyż dotyczą one obecności Rosji w Gruzji od 1801 do 1991 r. Poniższe rozważania dotyczą jednak głównie zabiegów prezydenta w kwestii pamięci (właściwie niepamięci) o radzieckiej historii Gruzji, a zatem usuwania pomników radzieckich i wybierania odpowiednich bohaterów narodowych, ustanawiania świąt narodowych, kreowania nowej symboliki państwowej oraz działań w obszarze badań naukowych i edukacji. Wszystko to miało podkreślać spuściznę europejskiej historii Gruzji i eliminować wszelką, nawet pozytywną, pamięć o radzieckiej przeszłości.

Micheil Saakaszwili wraz z dojściem do władzy po rewolucji róż w 2003 roku za cel postawił sobie stworzenie państwa silnego i niezależnego, które w żaden sposób nie będzie związane z przeszłością rosyjską. Widoczne było to już w samym dyskursie politycznym (Dundua, Karaia, Abashidze, 2017, s.238). Jak twierdzi prof. Malkhaz Toria, „odnowienie zapomnianej pamięci historycznej było ważnym celem rządu Gruzji po rewolucji róż w 2003 r. Postrzeganie Rosji jako historycznego agresora i okupanta stało się potężnym, nowym paradygmatem dla rządu, który służył jako strategia na rzecz wzmocnienia gruzińskiej tożsamości narodowej i integrowania ludności” (2016, s. 321). Po pogorszeniu się stosunków gruzińsko-rosyjskich w 2008 roku doświadczenie oporu było jedną z najwyraźniejszych politycznych tendencji, a polityka pamięci bezpośrednio wiązała się z bezpieczeństwem narodowym. Zdaniem prof. Torii „struktury władzy w czasie prezydentury Saakaszwilego za cel postawiły sobie zerwanie wszelkiego związku z przeszłością radziecką i postanowiły zaprowadzić ten plan na wszystkich poziomach życia społecznego. W tym celu wyznaczono zadanie wprowadzenia w kraju demokracji typu zachodniego, by wrócić do Europy i przeprowadzić zarówno polityczną, jak i mentalną rewolucję w gruzińskim społeczeństwie. Władze w tym czasie postanowiły pozbyć się wszystkich sowieckich symboli w państwie. Rewolucja róż stała się symbolem odrodzenia narodowego i początku nowej epoki historycznej. Jednocześnie zatem tworzone były symbole antyradzieckie i antyrosyjskie" (Ильин, 2013).

Pierwszy znaczący przypadek odstępstwa od dotychczasowych tradycji zdarzył się na początku prezydencji Saakaszwilego, gdy ten ogłosił motto swojej prezydentury brzmiące 
„Podążajmy za Dawidem Budowniczym”. Prezydent złożył przysięgę wobec Gruzji przy grobowcu króla Dawida Budowniczego, wypowiadając znamienne słowa: „Dzisiejsza Gruzja jest podzielona i upokorzona. Powinniśmy zjednoczyć się w celu przywrócenia integralności terytorialnej Gruzji. Gruzja istniała i będzie istnieć jako zjednoczony silny kraj” (Dundua, Karaia, Abashidze, 2017, s.234). Prezydent powiedział to przy grobowcu króla, który w XI wieku zjednoczył podzielone państwo gruzińskie, wyzwalając je spod panowania tureckiego, i tym samym zapoczątkował Złoty Wiek Gruzji. Odwołując się do Dawida, Saakaszwili zmienił również flagę narodową, hymn i godło oraz postawił w centrum Placu Wolności głównego placu Tbilisi - pomnik św. Jerzego, który miał symbolizować zjednoczone, silne państwo z rządem o nowym charakterze. Dawid Budowniczy, uznany za jednego z największych bohaterów Gruzji, stał się niejako symbolem prezydentury Saakaszwilego.

Zgodnie ze słowami Erica Hobsbawma „w trakcie procesu transformacji zasadnicze znaczenie historii przejawia się w potrzebie budowania nowych ideałów w celu konsolidacji społeczeństwa. Te nowe ideały zastępują zniszczone" (Hobsbawm, 2015, s. 12). Ta tendencja jest godna uwagi również w przypadku Gruzji, gdzie pamięć o bohaterach historycznych takich jak Dawid Budowniczy była wykorzystywana do konsolidacji narodu i budowania państwowości po siedemdziesięciu latach radzieckiej zależności. Znamienne jednak wydaje się to, że w przypadku Gruzji bohaterami narodowymi stawali się nie tylko wielcy władcy (jak Dawid czy Tamara), ale często także postacie ściśle związane $\mathrm{z}$ działaniami antyrosyjskimi. Po konflikcie gruzińsko-rosyjskim w 2008 roku kreowanie polityki pamięci przyjęło formę wiktymizacji, tworzenia w zbiorowej świadomości syndromu ofiary rosyjskiego imperializmu, co traktowane było priorytetowo również w kwestii problemu bezpieczeństwa narodowego. W dyskursie politycznym powszechnie używano terminów „okupacja”, „okupant”, „represje” itd. Ową historyczną narrację, formułowaną w związku z wojną sierpniową z 2008 r., można ocenić jako swego rodzaju rewolucję kulturową, której celem było zastąpienie mitu „kilkudziesięciu lat sojuza” pamięcią o „kilkudziesięciu latach okupacji”.

Jak wspominano już wyżej, wojna sierpniowa została przedstawiona przez władze gruzińskie jako inwazja rosyjska na terytorium Gruzji, analogiczna do bolszewickiej z 1921 roku. Szerzenie w przestrzeni publicznej przekonania, że Rosja nadal jest największym zagrożeniem dla integralności i niepodległości Gruzji, miało być próbą pokonywania radzieckiej spuścizny w gruzińskiej mentalności (Toria, 2016). Antyradziecka i antyrosyjska polityka historyczna Saakaszwilego obejmowała także tworzenie nowych miejsc pamięci i 
niszczenie tych związanych $\mathrm{z}$ sowiecką przeszłością. Jednym z najwyraźniejszych jej przejawów było utworzenie Muzeum Okupacji Sowieckiej w Tbilisi.

Muzeum otwarto 26 maja 2006 roku, w rocznicę utworzenia Demokratycznej Republiki Gruzji (1918). Podczas inauguracji prezydent Saakaszwili przedstawił je jako przykład postępu, jaki uczyniła Gruzja, od kiedy w 1921 jej terytorium zajęła Armia Czerwona, kończąc krótki okres niepodległości i doprowadzając do włączenia młodego państwa w skład Związku Socjalistycznych Republik Radzieckich. „Ominęliśmy wiele przeszkód i staliśmy się państwem. To oznacza, że nikt już nie zmusi Gruzji, by przed nim klękała jak w 1921 roku” - powiedział prezydent podczas ceremonii (Khinchagashvili, 2011). W jego przemówieniu dostrzega się nawiązanie do niebezpiecznej, imperialistycznej polityki Moskwy. „Gruzja stoi w obliczu pełnej kampanii oszczerstw, nacisków i szantażu - mówił Saakaszwili - jednak teraz nie wzięto pod uwagę najistotniejszego: Gruzja nie jest taka jak w 1921 roku” (Khinchagashvili, 2011). Prezydent wyraźnie podkreślał, że widzi Gruzję jako niezależne, silne, demokratyczne państwo, które w żaden sposób nie podda się naciskom rosyjskim, jak to miało miejsce w ubiegłym stuleciu. „To muzeum poświęcone jest Kakucy Czolokaszwilemu i jego braciom. To muzeum dedykowane jest podziemnym organizacjom utworzonym $\mathrm{w}$ tym okresie. To muzeum jest przeznaczone dla duchownych, prawie zniszczonych w ostatnim wieku. To muzeum poświęcone jest gruzińskiemu oficerowi. To muzeum poświęcone jest mojemu dziadkowi Nikuszy Tsereteliemu, który został wygnany na Syberię" - te słowa miały podkreślać, że owo miejsce pamięci stanowi pomnik wszystkich tych, którzy ginęli lub byli represjonowani od 1921 roku za walkę o niepodległość Gruzji (Dundua, Karaia, Abashidze, 2017, s. 236). Stanowią one znaczący obraz polityki Saakaszwilego, wynoszącej na piedestał wszystkich walczących z rosyjskim i radzieckim imperializmem.

Przestrzeń w muzeum została zaprojektowana bardzo czytelnie. Wyróżnione nazwiska oraz zdjęcia postaci, których dotknęły radzieckie represje, pojawiają się już na ścianie u samego wejścia, następnie przedstawiono historię Gruzji od 1918 roku (data utworzenia Demokratycznej Republiki), przez jej zajęcie przez bolszewików, aż po antyradzieckie protesty w Gruzji i upadek ZSRR. Dalej można zobaczyć mapę z okupowanymi po dziś dzień przez Rosję terenami - Abchazją i Osetią Południową. Choć podobne instytucje znajdują się chociażby na Ukrainie czy w państwach bałtyckich, fenomenem gruzińskiego muzeum jest to, że na końcu wystawy znajduje się część informacyjna, zgodnie z którą kierowana przez Saakaszwilego rewolucja róż pozwoliła się wyzwolić Gruzinom z radzieckiej mentalności. 
Po dwóch latach od otwarcia muzeum, po wspomnianej wojnie sierpniowej, na nowo pojawiło się pytanie o przełamanie sowieckiego dziedzictwa. Obok tworzenia miejsc pamięci związanych z reżimem radzieckim dużą wagę przykładano do burzenia miejsc, które z kolei pozytywnie nawiązywały do wspólnych kart gruzińsko-radzieckiej historii. Wypieranie pewnych faktów jest jednym z podstawowych założeń polityki historycznej, które uzasadnia się nowym oglądem racji historycznych (Ponczek, 2013). Przykładem takich działań jest sprawa pomnika Józefa Stalina stojącego w Gori - mieście, w którym urodził się przywódca ZSRR. Kwestia tego, jak przezwyciężyć pamięć o dyktatorze, stała się niezwykle dyskusyjnym tematem w Gruzji. Zdaniem rządu usunięcie pomnika Stalina było zabiegiem koniecznym. Zwrócono jednak uwagę, że sam jego demontaż nie jest wystarczającym działaniem, które pomogłoby usunąć sowiecką przeszłość z przestrzeni publicznej. Największym wyzwaniem okazała się walka z mitologizacją Stalina w mentalności Gruzinów, szczególnie tych mieszkających w Gori. W mieście tym dyktator był traktowany jak ikona, symbol patriotyzmu i gruzińskości, dlatego rządowa dyskusja na temat demontażu jego pomnika spotkała się $\mathrm{z}$ falą protestów mieszkańców i została nieoczekiwanie zakończona. Władze podjęły decyzję o usunięciu pomnika z centralnego placu i przeniesieniu go do Muzeum Stalina. Akcja została przeprowadzona o północy, by mieszkańcy nie mogli przeszkodzić w demontażu. Ministerstwo Kultury Gruzji podjęło decyzję o utworzeniu nowego „miejsca pamięci” na cokole posągu Stalina, które opisałoby rosyjską agresję, ale plan ten nigdy nie został zrealizowany. Znamienne jest to, że nie zamknięto samego Muzeum Stalina, które mieści się w centrum miasta, a wszelkie pomniki związane z dyktatorem zostały do niego przeniesione i stały się elementem wystawy powszechnie w Gruzji dostępnej (Dundua, Karaia, Abashidze, 2017, s. 236- 237).

Za najbardziej kontrowersyjne działania podjęte $\mathrm{w}$ ramach koncepcji usuwania $\mathrm{z}$ przestrzeni publicznej monumentów nawiązujących do radzieckiej przeszłości uważa się zniszczenie pomników pamięci wojny ojczyźnianej w Kutaisi i Batumi. Monument w Kutaisi wybudowano ku pamięci ofiar wielkiej wojny ojczyźnianej na początku lat 80., a zburzono go w 2009 roku, aby na jego miejscu wybudować nowy budynek parlamentu Gruzji, który miał zostać przeniesiony z Tbilisi. Przeciw demontażowi występowało wielu mieszkańców Gruzji, szczególnie członków partii opozycyjnych, którzy zbierali nawet podpisy przeciwko temu „aktowi wandalizmu”. Ostatecznie przy użyciu dynamitu pomnik został wysadzony 19 grudnia 2009 roku. Zburzenie pomnika było jednym z działań przeprowadzonych w celu obniżenia rangi wojny ojczyźnianej. Walczący w niej, traktowani do tej pory jak mężowie 
stanu, w oficjalnej historii zostali przedstawieni jako uczestnicy wojny, którą prowadził Związek Radziecki, a więc ówczesny okupant Gruzji. Od tego momentu w gruzińskiej historii miało nie być już miejsca dla takich bohaterów. Ta drastyczna dla społeczeństwa gruzińskiego zmiana spotkała się $\mathrm{z}$ wieloma protestami. W tym czasie podniesiona została również kwestia samej daty świętowania zakończenia wojny. Dotychczasowy 9 maja bezpośrednio nawiązywał do radzieckiej tradycji wygranej z Hitlerem, a zerwanie z nią oznaczałoby zmianę owej daty na 8 maja w nawiązaniu do podejścia zachodniego, w którego stronę miała się od tej pory zwracać Gruzja. Ustawa dotycząca daty obchodów zakończenia wojny nie została jednak przyjęta.

W Batumi z kolei od 1965 roku stał pomnik ofiar wojny - obelisk wzniesiony na cześć Gruzinów, którzy zginęli w wielkiej wojnie ojczyźnianej. 24 lutego 2012 roku rozpoczęła się jego likwidacja. Tego samego dnia zgaszono również płonący przy nim ,wieczny ogień”. Początkowo demontaż monumentu uniemożliwiali opozycjoniści, weterani i ruchy społeczne. Niezadowoleni mieszkańcy Batumi próbowali zapobiec rozbiórce pomnika - obalili ogrodzenie i położyli kwiaty na zgaszony wieczny ogień. Chociaż rząd przekazał ludziom informację, że monument zostanie przeniesiony $\mathrm{w}$ inne miejsce, zdecydowano się go po prostu zniszczyć. Demontaż zbiegł się z datą 25 lutego, czyli rocznicą zajęcia Gruzji przez Armię Czerwoną, Zdaniem zastępcy parlamentu Gruzji, Petra Mamradzego, „Zniszczenie pomnika było próbą zniszczenia wszystkiego, co wiązało Gruzję z Rosją" (B Баmyмu начался..., 2012).

Burzenie pomników wznoszonych ku czci bohaterów wojny ojczyźnianej jest ściśle związane z tworzoną przez Saakaszwilego na nowo hierarchią bohaterów narodowych. O ile od samego początku swej prezydentury Saakaszwili odwoływał się przede wszystkim do XIwiecznego władcy Dawida Budowniczego, o tyle decydując się na usunięcie z przestrzeni publicznej miejsc związanych z bohaterstwem nie tyle gruzińskim, co Związku Radzieckiego, na piedestał wyniósł postaci, których działalność związana była ściśle z walką z władzą radziecką. Wiązało się to również z faktem, że w ramach radzieckiej polityki pamięci historia wspominanej wyżej Demokratycznej Republiki Gruzji i jej działaczy niepodległościowych, zamordowanych przez bolszewików, przedstawiona była jako epizod w ramach wielkiego ruchu bolszewickiego w Gruzji, którego symbolicznym początkiem była rewolucja październikowa, a ostatnim punktem ustanowienie radzieckiej władzy w Gruzji w 1921 roku. Oficjalna historiografia radziecka i podręczniki szkolne traktowały DRG jako czas uwstecznienia (Toria, 2016, s. 330). Stąd też w ramach antyradzieckiej polityki 
Saakaszwilego postaci działające w ramach DRG zostały uznane za bohaterów narodowych. Sztandarowym przykładem jest tutaj wspominany już Kakuca Czolokaszwili, związany z powstaniem antysowieckim z 1924 roku. Portrety Czolokaszwilego zaczęły pojawiać się obok gruzińskiej flagi narodowej. W tym czasie jego nazwisko było znane nielicznym ludziom, ale popularność rosła $\mathrm{z}$ dnia na dzień i wkrótce stał się jedną z wiodących postaci panteonu bohaterów narodowych prezentowanych w szkolnych podręcznikach do nauki historii (Chikovani, 2013, s.79). W 2005 roku jego zwłoki przewieziono do panteonu Mtacminda w Tbilisi. W uroczystym pogrzebie uczestniczyły najważniejsze osobistości życia publicznego Gruzji oraz tysiące mieszkańców kraju z różnych regionów. Jego portret został umieszczony na banknocie o nominale 200 lari. Imieniem Czolokaszwilego nazwano jedną z ulic w popularnym dystrykcie Wake w Tbilisi, w którym znajduje się ambasada rosyjska (Toria, 2016, s. 332). Nazwisko Czolokaszwilego pojawiło się również na wzniesionym w 2009 roku pomniku ku czci bohaterów gruzińskich na placu Bohaterów w Tbilisi, gdzie wyryte w marmurze są przede wszystkim nazwiska gruzińskich kadetów, którzy zmarli w walce $\mathrm{z}$ Armią Czerwoną w 1921 r., przywódców antysowieckiego buntu z 1924 r. oraz tych, którzy zginęli podczas działań wojennych w Abchazji w latach 1992-1993 i w wojnie pięciodniowej w Osetii Południowej w sierpniu 2008 r. - łącznie około 4000 nazwisk.

W 2011 roku dzień 25 lutego został wyznaczony w oficjalnym kalendarzu świąt Dniem Okupacji Sowieckiej. Ustawa dotycząca święta została przyjęta przez parlament (większością 87 na 110 deputowanych) 21 lipca 2010 roku (Dundua, Karaia, Abashidze, 2017, s.238). Co roku, w rocznicę zajęcia Gruzji w 1921 roku przez armię radziecką, flagi państwowe spuszczane są do połowy masztu i ogłaszana jest minuta ciszy. Warto wspomnieć, iż w tymże 2011 roku parlament Gruzji zatwierdził także tak zwaną Kartę Wolności, zakazującą używania symboli radzieckich w przestrzeni publicznej. Karta Wolności składa się z trzech głównych zasad: wzmocnienia bezpieczeństwa narodowego, zakazu nawiązywania do radzieckich i faszystowskich ideologów oraz nakazu usuwania wszelkich związanych z nimi symboli. Karta ta została przygotowana przez Gię Tortladzego, członka opozycji, lecz jednogłośnie poparła ją rządząca partia Zjednoczonego Ruchu Narodowego. Zabrania ona istnienia komunistycznej partii radzieckiej, a na jej mocy byli funkcjonariusze służb specjalnych zostali objęci zakazem sprawowania urzędowych stanowisk w parlamencie, rządzie i urzędach bezpieczeństwa. Z jednej strony wejście w życie Karty było symbolicznym gestem (głównym jej celem było uniemożliwienie niektórym współpracownikom udziału we współczesnej polityce), z drugiej zaś wielu polityków podkreślało przede wszystkim, iż jej 
przyjęcie jest ostatecznym zerwaniem z radziecką przeszłością Gruzji (Georgia mulls..., 2009).

Polityka pamięci ma wyraźny wpływ na edukację danego kraju. W czasie prezydentury Saakaszwilego wprowadzone zostały nowe podręczniki do nauki historii Gruzji, w których pierwsza Demokratyczna Republika Gruzji jest interpretowana jako skomplikowany i kontrowersyjny okres historii tego państwa w XX wieku. Przedstawia się ją jako państwo zjednoczone, wieloetniczne i demokratyczne, które było pierwszym krokiem ku powstrzymaniu reżimu radzieckiego. Z ramienia Ministerstwa Nauki i Edukacji wystąpiono również z propozycją wydania specjalnego podręcznika do nauki historii Gruzji, poświęconego historii okupacji rosyjskiej w latach 1801-1991 (Toria, 2016, s. 332). Postanowiono też co roku oprócz obchodów związanych z agresją Armii Czerwonej na Gruzję (25 lutego) wyznaczać „Tydzień rosyjskiej okupacji”, w ramach którego prowadzono publiczne wykłady w gruzińskich szkołach średnich. Przykładem może być konferencja młodzieżowa przeprowadzona w szkole nr 37 w Kutaisi w lutym 2009 r., na której uczniowie prezentowali swoje prace o radzieckiej inwazji na Gruzję. Referaty dotyczyły takich tematów jak: „Przygotowanie rosyjskiej inwazji na Gruzję”, „Sowiecka okupacja Gruzji” i „Gruzińska młodzież w czasie okupacji” (Kldiashvili, 2009).

Wartym podkreślenia krokiem Saakaszwilego w dziedzinie samej edukacji było też wycofanie obowiązku nauczania języka rosyjskiego. Do 2005 roku język rosyjski nauczany był w szkołach jako drugi język, od 2005 roku- otrzymał status języka obcego, którego nauczanie nie jest obowiązkowe, a uczniowie, którzy od 3 klasy uczęszczają na obowiązkowe lekcje języka angielskiego, zamiast rosyjskiego mogą w wieku 11 lat wybrać język francuski czy niemiecki. Saakaszwili podkreślał: „Zawsze mówiłem, że jestem może ostatnim, może przedostatnim prezydentem Gruzji, który umie zacytować Puszkina, Lermontowa, Brodskiego, Jesienina. Odejdzie to pokolenie i przyjdzie nowe, które nie będzie rozumieć, czym jest i gdzie się znajduje Rosja” (Президент Грузии..., 2010).

Dariusz Gawin w artykule pt. Polityka historyczna i demokratyczne państwo pisze: „Dziś wyraźnie widać już, że demokracja nie może pracować dla przyszłości, jeśli nie jest jednocześnie wspólnotą pamięci” (Gawin, 2015). Gruzja, „ucząc się” demokracji, stanęła przed wyzwaniem wykreowania odpowiedniej polityki pamięci, która miała kształtować naród gruziński w nowej przestrzeni postsocjalistycznej. Zabiegi podejmowane w tym celu przez władze przed rewolucją róż można uznać za nacjonalistyczne bądź ambiwalentne - 
sama strategia uprawiania polityki historycznej nie została przygotowana i przemyślana. Micheil Saakaszwili po objęciu urzędu prezydenta zaproponował zupełnie nowy projekt polityki pamięci, który można określić jako wyraźnie antyrosyjski i antyradziecki. Projekt ten miał integrować społeczeństwo gruzińskie przez stworzenie obrazu głównego wroga narodu Rosji. Jego celem było oderwanie Gruzji od spuścizny Związku Radzieckiego i nawiązywanie do europejskiej, demokratycznej historii kraju. Nowe elity postanowiły spalić „mosty mentalne" łączące Gruzinów z Rosją i utworzyć nowe miejsca pamięci. Synonimem „sowietyzacji” Gruzji stała się „okupacja” (zarówno na poziomie mediów, prawa, jak i nauki). Nowy panteon bohaterów narodowych, nowy sposób nauczania historii w szkołach i nowa symbolika państwowa sprawiły, że pamięć o Związku Radzieckim przybrała formę wspomnienia okupacji, której kres zadała dopiero rewolucja róż.

Polityka pamięci prezydenta odznacza się w swej antyrosyjskości i antyradzieckości dużą drastycznością i podejściem niejako rewolucyjnym. Dochodząc do władzy w 2003 roku, Saakaszwili został liderem kraju, który wydał jednego z głównych przywódców radzieckich i w którym przywiązanie do sowieckiej przyszłości było wyjątkowo silne - zarówno w świadomości społeczeństwa, jak i w przestrzeni prawnej czy kulturowej. Micheil Saakaszwili postanowił jednak wywołać rewolucję w gruzińskiej mentalności, wykorzystując w tym celu antyrosyjskie zabiegi w polityce pamięci. Nie ulega wątpliwości, że spotkały się one z dużym oporem ze strony społeczeństwa, niemniej były ważną częścią projektu mającego transformować Gruzję w kraj, w którym naród czuje związek przede wszystkim ze swoją europejską i demokratyczną historią, a przeszłość sowiecką traktuje wyłącznie jako czas okupacji niepodległego kraju.

\section{BIBLIOGRAFIA}

Chikovani N., The De-Sovietisation and Nationalization of History in Post-Soviet Georgia, [w:] O. Karpenko, J. Javakhishvili (eds.), Myths and Conflicts in the South Caucasus, vol. 1: Instrumentalisation of Historical Narratives, online: http://cisr.ru/files/publ/Caucasus_2013_Myths_Vol1_EN1.pdf-25 IX 2017.

Dundua S., Karaia T., Abashidze Z., 2017, National narration and Politics of Memory in post-socialist Georgia, „Slovak Journal of Political Sciences”, Vol. 17, No. 2, online: https://www.degruyter.com/downloadpdf/j/sjps.2017.17.issue-2/sjps-2017-0010/sjps-20170010.pdf 
Gawin D., Polityka historyczna i demokratyczne państwo, http://www.teologiapolityczna.pl/polityka-historyczna-i-demokratyczne-panstwo-tekstdariusza-gawina-2/

Georgia mulls banning ex-KGB members from public office, 2009, „BBC News”, 26 XI, online: http://news.bbc.co.uk/1/hi/world/europe/8380250.stm - 25 IX 2017.

Hobsbawm E., 2015, Introduction: Inventing Traditions, [w:] E. Hobsbawm, T. Ranger (eds.), The Invention of Tradition, Cambridge.

Khinchagashvili Sh., 2011, A Georgian Perspective on Memory Conflicts, „Memory at War: Blog", 29 V, online: http://cambridgeculturalmemory.blogspot.com/2011/05/georgianperspective-on-memory.html - 25 IX 2017.

Kldiashvili N., 2009, 1921 tslis 25 t'ebervali, okupatsiis kvireuli, , 2 II, online: http://okupacia1921.blogspot.com/2009/03/37.html - 25 IX 2017.

Ponczek E., 2013, Polityka wobec pamięci versus polityka historyczna: aspekty semantyczny, aksjologiczny i merytoryczny w narracji polskiej, „Przegląd Politologiczny”, nr 2, online: http://przeglad.amu.edu.pl/wp-content/uploads/2013/09/pp-2013-2-007-022.pdf -25 IX 2017.

Toria M., 2016, The Soviet occupation of Georgia in 1921 and the Russian-Georgian war of August 2008. Historical analogy as a memory project, [w:] S. F. Jones (ed.), The making of modern Georgia, 1918-2012. The first Georgian republic and its succesors, London.

Wawrzyński P., 2013, The Past, Polish Politics of Memory, and Stereotyping: an intercultural perspective, online:

http://www.academia.edu/7162078/The_Past_Polish_Politics_of_Memory_and_Stereotyp ing_an_intercultural_perspective_on-line - 25 IX 2017.

В Батуми начался демонтаж памятника советским солдатам, 2012, „Georgia Times", 24 II, online: http://www.georgiatimes.info/news/72447.html - 25 IX 2017.

Ильин В., 2013, „Войны памяти” в Грузии, „«7х7» Горизонтальная Россия”, 29 Х, online: https://7x7-journal.ru/post/33672 - 25 IX 2017.

Президент Грузии не понимает претензий, предъявляемых ему Россией, 2010, „РИА Новости", 16 VII, online: https://ria.ru/world/20100716/255246843.html - 1 IX 2017. 
Саакашвили: В Грузии решается судьба нового мирового порядка, 2008, „Корреспондент. нет”, 17 VII, online: http://korrespondent.net/world/525856-saakashviliv-gruzii-reshaetsya-sudba-novogo-mirovogo-poryadka - 25 IX 2017.

\section{Biogram}

Anna Pająk - doktorantka w Instytucie Nauk Politycznych i Stosunków Międzynarodowych UJ oraz studentka studiów II stopnia na kierunku studia eurazjatyckie. Absolwentka studiów I stopnia na kierunku filologia ukraińska oraz kulturoznawstwo, specjalność: rosjoznawstwo, a także studiów II stopnia na kierunku kulturoznawstwo, specjalność: ukrainoznawstwo. W pracy badawczej zajmuje się szeroko pojętą tematyką kaukaską ze szczególnym uwzględnieniem polityki historycznej oraz konfliktów etnicznych w regionie. 